\title{
In Vivo RNA Interference of a Gonad-Specific Transforming Growth Factor- $\beta$ in the Pacific Oyster Crassostrea gigas
}

\author{
Arnaud Huvet ${ }^{a}{ }^{*}$, Elodie Fleury ${ }^{b}$, Charlotte Corporeau $^{a}$, Virgile Quillien ${ }^{a}$, Jean Yves Daniel ${ }^{a}$, \\ Guillaume Riviere $^{c}$, Pierre Boudry ${ }^{a}$ and Caroline Fabioux ${ }^{d}$
}

\author{
a IFREMER, UMR Physiologie et Ecophysiologie des Mollusques Marins, Technopole Brest-Iroise, BP70, 292800 \\ Plouzané, France \\ ${ }^{\mathrm{b}}$ IFREMER, Station de la Trinité sur Mer, LER/MPL, 56470 La Trinité Sur Mer, France \\ c Université de Caen-Basse Normandie, UMR Physiologie et Ecophysiologie des Mollusques Marins, 14032 \\ Caen Cedex, France \\ d Institut Universitaire Européen de la Mer, Université de Bretagne Occidentale, LEMAR, UMR 6539 \\ CNRS/UBO/IRD, 29280 Plouzané, France
}

*: Corresponding author: Arnaud Huvet, Tel.: +33 (0)2 98224693 ; Fax : +33 (0)2 98224653 email address : ahuvet@ifremer.fr

\begin{abstract}
:
We investigated the role of oyster gonadal TGF $\beta$ (og-TGF $\beta$ ) in the reproduction of Crassostrea gigas, using an in vivo RNA interference approach. We designed double-stranded RNA targeting og-TGF $\beta$, which is specifically expressed in the somatic cells surrounding germ cells in the gonad of both male and female oysters. In vivo injection of this og-TGF $\beta$ dsRNA into the gonad led to knock-down phenotypes for both sexes, with significant reduction $(77.52 \%$ relative to controls) of the gonad area, lowered reproductive effort and germ cell under-proliferation. Interestingly, half of the injected females halted their vitellogenesis, since we were only able to observe pre-vitellogenic oocytes. In addition, apoptotic germ cells and haemocytes infiltrated into the gonad, likely as part of the active resorption of degenerating germ cells. Conversely, males showed a normal phenotype at the cellular level, with spermatids and spermatozoids observed in the gonads of control and injected males. As a result, ogTGF $\beta$ appears to play an essential role in $C$. gigas germ cell development by functioning as an activator of germ cell proliferation in both male and female oysters and vitellogenesis in females.
\end{abstract}

Keywords: Marine bivalve - Crassostrea gigas - Reproduction - RNA interference - Transforming growth factor- $\beta$ 


\section{Introduction}

Elucidating the molecular bases of resistance to summer mortality in the Pacific oyster Crassostrea gigas, a phenomenon severely affecting the oyster production industry in several countries, is an important way of finding potential solutions to this problem and improving our knowledge of the biology of this species (Samain et al., 2007; Samain \& McCombie, 2008). Resistance has been demonstrated to be highly heritable (Dégremont et al, 2007; 2010) and the first Quantitative Trait Loci (QTL) for resistance to summer mortality have been successfully identified (Sauvage et al., 2010). However, the low density of currently available linkage maps, together with the fact that we do not know the whole genome sequence (Hedgecock et al., 2005), limits the potential of such approaches to identify genes involved in resistance. Alternatively, genome-wide expression profiling comparing Pacific oyster lines selected as resistant and susceptible to summer mortality has identified candidate genes that could form the genetic basis of summer mortality resistance (Fleury et al., 2010). Among these candidates, oyster-gonadal-TGF $\beta$ (og-TGF $\beta$ ), which belongs to the Transforming Growth Factor $\beta$ family, deserves specific attention as it appears to be co-localized in one of the five QTL associated with summer survival (Sauvage et al., 2010) and could supposedly have a role that is beneficial to oyster survival (Fleury et al., 2008).

Knowledge of spatio-temporal expression patterns of a given gene is valuable for assigning its function. Og-TGF $\beta$ is specifically expressed in the somatic cells surrounding oocytes and spermatocytes in male and female gonads, and reaches maximal levels in fully mature oysters (Fleury et al., 2008). This expression pattern suggests a potential role for Og-TGF $\beta$ in reproduction, germinal cell proliferation and/or maturation (Fleury et al., 2008). Additionally, in other animal species, some members of the TGF- $\beta$ superfamily exhibit specific roles in reproduction by regulating the function of the ovary or testis (Itman et al., 2006; Knight \& Glister, 2006; Sawatari et al., 2007; Gautier et al., 2011) or throughout the reproductive system (Shimasaki et al., 2004). Based on the og-TGF $\beta$ expression patterns measured in oyster lines selected as resistant and susceptible to summer mortality, og-TGF $\beta$ supposedly has a negative effect on oyster gonad development, which could be of benefit to oyster survival (Fleury et al., $2008 ; 2010)$. This hypothesis is supported by the negative correlation observed between reproductive effort and survival (e.g., Ernande et al., 2004; Samain et al., 2007; Huvet et al., 2010). A negative effect has already been observed for some TGF $\beta$ members, such as TGF $\beta 1$, AMH or some BMP15 in vertebrates (Kohli et al., 2005; Josso et al., 1998; Moore et al., 2004).

Aside from the information provided by tissue-specific expression patterns, gene functions are primarily assessed on the basis of altered phenotypes associated with gene disruption or protein inactivation. In a recent study, researchers induced in vivo functional inactivation of mature ogTGF $\beta$ in $C$. gigas through heterologous pan-specific anti-TGF $\beta$ polyclonal antibody injection into the oyster gonad (Corporeau et al., 2011). The inhibition of og-TGF $\beta$ function led to a small reduction in gonadal area, suggesting that mature og-TGF $\beta$ probably functions as an activator of germ cell development in oyster, in opposition with the previous hypothesis proposed in Fleury et al. (2008). Some TGF $\beta$ members are also known to be potent stimulators of folliculogenesis and ovulation quota, especially in mammals (Vitt \& Hsueh, 2001, Knight \& Glister, 2006). The antibody used by Corporeau et al. (2011) had initially been produced to be effective in a large range of species, from humans to amphibians, meaning that, though these researchers directed it against the C-terminal mature part of TGF $\beta$ (Biswas et al., 2006; Ma et al., 2004), it would supposedly be able to neutralize the biological activity of several TGF $\beta$ members in oyster. 
To evaluate the potential role of og-TGF $\beta$ in oyster more specifically in the present study, we used RNA interference technology (Fire et al., 1998; Hannon, 2002). This method offers the advantage of a selective disruption of the target gene, with high expected degrees of efficiency and specificity (e.g., Elbashir et al., 2001). Based on the recent development of RNA interference in C. gigas (Fabioux et al., 2009), dsRNA targeting the og-TGF $\beta$ gene was injected in vivo into oysters that were then analysed for their gametogenic development by histological methods and for their expression levels of og-TGF $\beta$ using real-time PCR.

\section{Material and methods}

\subsection{Biological material}

We produced the oysters for this study in 2007 at the Ifremer hatchery in La Tremblade (Charente Maritime, France) by crossing 30 wild parental oysters collected in the MarennesOléron Bay. We then sent the progeny to be cultured in the Quiberon bay (Morbihan, France). In March 2009, we transferred the oysters, now two years old, to Ifremer's experimental facilities in Argenton (Finistère, France). At this point they were at stage 0 to early stage 1 , corresponding to undifferentiated or developing early active gametogenesis according to the reproductive scale of Steele \& Mulcahy (1999). We then conditioned them for 2 months under suitable conditions for germ cell maturation. Briefly, we placed the oysters in experimental raceways supplied with $20 \mu \mathrm{m}$-filtered running seawater at $19 \pm 1.0^{\circ} \mathrm{C}$ and fed them on a mixed diet of three microalgae at a daily ration equal to $8 \%$ dry weight algae / dry weight oyster (see Fabioux et al., 2005 for details on oyster conditioning).

\section{2. dsRNA synthesis}

The procedure we used is similar to that described by Fabioux et al. (2009). We amplified a fragment from positions 717 to 1142 of og-TGF $\beta$ cDNA (GenBank accession EF563990) by RTPCR using total RNA extracted from gonad as template. We then sub-cloned the PCR fragment into pCR4-TOPO vector (Invitrogen, Paisley, UK) and sequenced it. We purified the recombinant plasmid using the Plasmid midi kit (Qiagen), linearised it with either Notl or Spel (Promega, Madison, WI) enzymes (4 $\mathrm{h}$ at $37{ }^{\circ} \mathrm{C}$ using $5 \mathrm{U} / \mu \mathrm{g}$ plasmid), then phenol-chloroform extracted and finally ethanol-precipitated and suspended it in RNAse-free water. We then transcribed both strands of the purified plasmid in vitro using T7 and T3 MEGAscript ${ }^{\circledR}$ Kits (Ambion, Austin, TX, USA) to produce og-TGF $\beta$ sense and antisense single stranded RNA (sSRNA). We phenolchloroform extracted the ssRNA and ethanol-precipitated and suspended it in RNAse free saline solution $(10 \mathrm{mM}$ Tris $/ 10 \mathrm{mM} \mathrm{NaCl})$ to obtain a final concentration of $0.5 \mu \mathrm{g} / \mu \mathrm{L}$ after quantification by spectrophotometry (Nanodrop, Thermo Scientific). We then heated equimolar amounts of sense and antisense ssRNA to $100{ }^{\circ} \mathrm{C}$ for $1 \mathrm{~min}$ and left to cool at room temperature for 10 hours for annealing. Finally, to ensure that the dsRNA consisted of a single band of $426 \mathrm{bp}$, we analysed a $1 \mu \mathrm{g}$ sample by $1 \%$ agarose gel electrophoresis .

\section{3. dsRNA administration and sampling}

We anesthetized oysters in $\mathrm{MgCl}_{2}$ solution (3/5 fresh water, $2 / 5$ seawater with $50 \mathrm{~g} / \mathrm{L} \mathrm{MgCl}_{2}$ ) for 5 hours (Suquet et al., 2009). We injected the anesthetized oysters in the gonad at T0, T7 (7 days) and T14, either with $53 \mu \mathrm{g}$ og-TGF $\beta$ dsRNA diluted in $100 \mu \mathrm{L}$ saline solution $(\mathrm{N}=30)$ or with the 
same volume of saline solution for the control $(N=24)$. After injection, we maintained the oysters in raceways in conditions allowing optimal gonad maturation.

At T9, we sampled 12 oysters injected with $53 \mu \mathrm{g}$ og-TGF $\beta$ dsRNA and 12 control oysters. At T34, we sampled 11 oysters injected with $53 \mu \mathrm{g}$ og-TGF $\beta$ dsRNA and 11 control oysters. We immediately dissected the gonads from these oysters, making a transversal section of the gonadal area for histological examination. The rest of the gonad we froze immediately in liquid nitrogen, then crushed to a fine powder at $-196{ }^{\circ} \mathrm{C}$ with a Dangoumau mill and stored in liquid nitrogen until RNA extraction.

\subsection{Histology}

We assayed gonadal development on histological slides of a transversal section of the whole gonadal area for dsRNA-injected and control oysters at T0, T9 and T34 according to Fabioux et al. (2005). For each sample, we excised a 3-mm cross section of the visceral mass in front of the pericardic region and immediately fixed it in modified Davidson's solution (Latendresse et al., 2002) at $4{ }^{\circ} \mathrm{C}$ for $48 \mathrm{~h}$. We dehydrated the sections in ascending ethanol solutions, cleared them with the xylene substitute Microclearing (Diapath, Italy), and embedded them in paraffin wax. We then cut sections of $5 \mu \mathrm{m}$, mounted them on glass slides and stained them with Harry's hematoxylin-eosin Y (Martoja \& Martoja-Pierson, 1967). We examined the slides under a light microscope to determine sex and the gametogenic stage according to the reproductive scale of Steele \& Mulcahy (1999). We determined percentage areas of gonadal tubules, conjunctive tissue and digestive gland on each histological section and then scanned the slides with a digital scanner (hp scanjet 7400c) and saved the images in *.TIFF format. We measured the tissue areas using image analysis software (Imaq Vision Builder, National Instruments Corp.). We estimated gonad area percentage as pixel number on the gonad / pixel number on total sections, as described in Fabioux et al. (2005). Finally, for each female, we measured the diameter of 25 oocytes randomly chosen on histological slides using Image-Pro Express v 6.0 software (Media Cybernetics Inc.).

\subsection{Real-time RT-PCR analysis}

We isolated the total RNA from each sample using Extract-all (Eurobio), at a concentration of

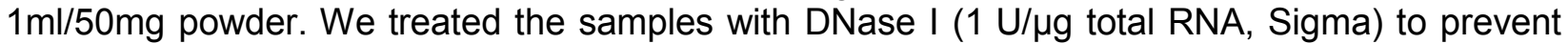
DNA contamination. We then assessed RNA quality using RNA nanochips and Agilent RNA 6000 nanoreagents (Agilent Technologies, Waldbronn, Germany), according to manufacturer's instructions. We measured RNA concentrations using an ND-1000 spectrophotometer (Nanodrop Technologies) at 260nm, using the conversion factor $10 D=40 \mu \mathrm{g} / \mathrm{mL}$ RNA. We carried out RT-PCR amplifications from $2 \mu \mathrm{g}$ of total RNA as described in Fabioux et al. (2004), using specific primers for og-TGF $\beta$ (primers detailed in Fleury et al., 2008) and actin primers (forward 5'-GCCCTGGACTTCGAACAA-3'; reverse 5'-CGTTGCCAATGGTGATGA-3') designed from C. gigas actin sequence (Cadoret et al., 1999)). We determined PCR efficiency $(E)$ for each primer pair by performing standard curves from serial dilutions to ensure that $E$ ranged from 98 to $100 \%$. We calculated the relative mRNA levels of the target gene using the comparative $\mathrm{Ct}$ method (Livak \& Schmittgen, 2001) and normalized to actin, as no significant differences of $\mathrm{Ct}$ values were observed for actin between control and og-TGF $\beta$ dsRNA-injected oysters (KruskallWallis test $=0.23 ; P=0.89, \mathrm{CV}=7.6 \%$ ). Consequently, we express relative mRNA levels in "numbers of copies of target gene per copies of actin". 


\subsection{Statistical analyses}

We performed statistical analyses with STATGRAPHICS software, using one-way analyses of variance followed by multiple comparison tests with the Tukey's HSD method. Before analysing percentage gonad area, we made angular transformations. For comparisons of sex and gametogenic stage distributions between treatments we used Chi-square tests.

Using the same software, we applied Student's t-tests to test the linear regression between the area occupied by the gonad and og-TGF $\beta$ mRNA level after transforming the values using a base 10 logarithmic transformation and "log values", which we then median centred. We considered differences to be statistically significant at $\mathrm{P}<0.05$.

\section{Results}

\subsection{Gene expression}

To validate the in vivo og-TGF $\beta$ dsRNA administration and its effectiveness in oysters, we assayed og-TGF $\beta$ mRNA level using real-time PCR. We observed a mean significant reduction of $77.52 \%$ in og-TGF $\beta$ mRNA level, relative to actin mRNA level at 34 days post-injection in dsRNA-injected oysters compared with the controls $(p=0.009)$. Mean levels of og-TGF $\beta$ mRNA were $10.55 \pm 0.49$ for controls and $2.37 \pm 1.48$ for dsRNA-injected oysters (Figure 1$)$. As proposed by Jiang et al. (2006), we considered a $70 \%$ inhibition of mRNA levels after dsRNA treatment as a threshold indicating effective RNA interference. In our experiment, this $70 \%$ threshold was attained for 8 out of the 11 analysed oysters injected with dsRNA (Figure 1).

\subsection{Semi-quantitative histology}

One month post-injection (T34), the oysters we had injected with og-TGF $\beta$ dsRNA showed a significantly lower mean gonad area $(22.93 \pm 19.37 \%)$ than controls $(37.82 \pm 18.34 \%)$. At the individual level, more than $80 \%$ (9 out of 11) of the dsRNA-injected oysters showed a reduced gonad area relative to the control oysters, with values ranging from 0.28 to $33.94 \%$ of total area of the visceral mass on histological sections (Figure 1). The two remaining dsRNA-injected oysters (1T and 25T) displayed a gonad area similar to those of the controls (42.60 and 66.56 $\%$, respectively). Interestingly, these two oysters are also among the three (15T, 1T and 25T) that had unaltered og-TGF $\beta$ mRNA levels. For oysters injected with og-TGF $\beta$ dsRNA, a strong correlation was observed between gonad area and og-TGF $\beta$ mRNA level $\left(R^{2}=0.82, p<0.01\right)$.

\subsection{Sex ratio and gametogenic stages}

Due to the alternative and irregular protandrous hermaphroditism of the Pacific oyster, we also examined sex-ratio (males / males + females + undifferentiated) through histological analysis. At T9, the sex ratio was exactly the same in control and injected groups. At T34, however, it varied from $27.27 \%$ in og-TGF $\beta$ dsRNA-injected oysters to $45.45 \%$ in controls (Table 1), although these alterations were not statistically significant.

At T34, 10 out of $11(90.9 \%)$ control oysters were in stage 3, corresponding to ripeness, and 6 out of $11(54.54 \%)$ og-TGF $\beta$ dsRNA-injected individuals showed mature germ cells in their gonadal tubules (Table 1). Among the dsRNA-injected individuals that showed mature germ cells, only $50 \%$ showed well developed gonadal tubules with a large number of ripe germ cells, 
and the others presented a limited number of mature gametes. The rest of the injected animals were in stage 2 , the germ cell post-mitotic stage (3 out of 11); stage 1, the germ cell proliferation stage ( 1 out of 11) and stage 0 , the pre-mitotic or "resting" stage (1 out of 11). Even though we noted some variation of stage distribution between groups, we observed no significant differences between control and injected groups at the $5 \%$ level, probably due to the low number of individuals analysed. It is also important to consider that the cellular structure of the gonad appeared extremely variable for the injected group. Consequently, we based the classification on the most developed germ cells of the developing tubules, whereas the classification into distinct gametogenic stages is usually based on observations of the whole gonad (Steele \& Mulcahy, 1999).

\subsection{Cellular characterization}

In the histological examination at T34, gonads of 10 out of 11 control oysters appeared mature. Gonadal tubules were confluent and filled with mature germ cells, i.e., oocytes for females or spermatozoids for males. For og-TGF $\beta$ dsRNA-injected oysters, $63.63 \%$ (7/11) presented a knock-down phenotype with less developed gonadal tissue than controls, due to a reduced number of germ cells in the tubules of both males and females upon microscope examination (Figure 2). For these females, mean oocyte diameter $(48.77 \pm 4.67 \mu \mathrm{m})$ appeared similar to that of the control females $(48.26 \pm 4.69 \mu \mathrm{m})$. The severity of the knock-down phenotype varied between individuals. The most severe phenotype we observed was for one oyster that did not start germ cell proliferation but instead remained at the reproductive resting stage (stage 0 , sex undifferentiated) with only rare germinal stem cells scattered in the conjunctive tissue (Figure 2). For $50 \%$ of females showing a reduction in germ cell number, the maturation of oocytes was prematurely curtailed compared with the gonads of the control oysters (Figure 3 ). These cells did not enter vitellogenesis since only pre-vitellogenic oocytes could be observed in the gonad. For these females, the gonad area reduction resulted from reduction in the number and size of germ cells (mean oocyte diameter $=22.00 \pm 9.43 \mu \mathrm{m}$ ) due to the presence of earlier developmental stages of germ cells, known to be smaller in diameter (Lango-Reynoso et al., 2000). Moreover, in some females, gonadal tubules contained apoptotic germ cells and haemocytes infiltrated into the gonadal area, likely corresponding to an active resorption of degenerating germ cells (Figure 3). Conversely, we observed no abnormal cytological figures on histological slides of males, even though the germ cell number appeared to be reduced compared with controls. We observed spermatids and spermatozoids in all og-TGF $\beta$ dsRNA-injected males and control males (Figure 2).

\section{Discussion}

\subsection{Design of the Og-TGF $\beta$ RNAi experiment on oysters}

Because long dsRNA have been demonstrated to perform efficient gene silencing in the Pacific oyster (Fabioux et al., 2009), we synthesised a long og-TGF $\beta$ dsRNA by in vitro transcription. The dsRNA was designed to be outside the sequence amplified by real-time PCR primers so as to avoid any bias from the injected dsRNA when quantifying mRNA. We demonstrated that direct injection into the gonad was an efficient method for administrating dsRNA to oyster tissues (Fabioux et al., 2009). As expression of og-TGF $\beta$ appears to be restricted to the gonad, we administrated og-TGF $\beta$-dsRNA into the gonad following the protocol already published in Fabioux et al. (2009). As already observed when targeting the oyvlg gene (Fabioux et al., 2009), we saw variability in RNAi response between individuals, which was probably due to variation in 
their reproductive status at T0 (the point at which we injected the dsRNA) and in the amount of dsRNA that actually penetrated into the germ cells. Indeed, around $20 \%$ of individuals injected with og-TGF $\beta$ showed no significant knock-down phenotypes, whereas the reproductive characteristics of the others showed a decrease in the number of gametes produced in both sexes and defective germ cell maturation in females. Although we did not observe any specific phenotype in several injected animals, the numerous challenges of in vivo RNAi due to multiscale barriers, including failure to accurately administrate, rapid excretion and poor cellular uptake (Shim \& Kwon, 2010), probably contributed to the variability in RNAi response.

\subsection{The role of og-TGF $\beta$ in oyster reproduction}

The Transforming-Growth-Factor- $\beta$ (TGF $\beta$ ) family is a structurally conserved but functionally diverse group of extracellular signalling proteins widely distributed in metazoans (Herpin et al., 2004). Members of the TGF $\beta$ superfamily are known to play important roles in cell proliferation and differentiation during development and in various physiological processes (ten Dijke et al., 2000). In C. gigas, recent findings demonstrate the occurrence of a diversity of TGF $\beta$ signalling components including various ligands, three subfamily type I receptors, two BMP/activin type II receptors and most of the Smad downstream transducers (see Herpin et al., 2004; Herpin et al., 2005; Le Quéré et al., 2009).

Oyster-gonadal-TGF $\beta$ was classified as a derived member within the TGF $\beta$ superfamily (Fleury et al., 2008). Its expression, which occurs when germ cells mature, appeared to be gonadspecific and exclusively located in somatic cells surrounding oocytes in females and spermatogonia in males. This expression pattern contrasts singularly with the pleiotropic roles commonly ascribed to most TGF $\beta$ members in a variety of physiological processes (ten Dijke et al., 2000). Some key components of the TGF $\beta$ system exhibit specific roles throughout the reproductive system of animals (Itman et al., 2006; Knight \& Glister, 2006; Shimasaki et al., 2004). In Drosophila, the TGF $\beta$ signal-transduction pathway has been determined to affect germ-line stem cell number and the size of the stem cell niche (Schulz et al., 2004). This effect has also been observed for GSDF in rainbow trout, which has a specific proliferation-enhancing effect on spermatogonia and probably also has an effect on oocyte maturation (Sawatari et al., 2007). Here, we showed that og-TGF $\beta$ would have a specific proliferation enhancing effect on male and female mitotic germ cells, germinal stem cells and gonia, plus a possible maturation effect on oocytes, as observed for GSDF in trout. Indeed, the most striking effect of in vivo ogTGF $\beta$ dsRNA injection into the oyster gonad, when injected at the initiation of gametogenesis, was a reduction in number of germ cells in both males and females compared with the controls. This resulted in the reduction of the gonad area. Indeed, when the median part of the visceral mass was examined, the percentage surface occupied by the gonad was directly linked to the number and/or size of gametes produced (Huvet et al., 2010). When we examined the gonad area reduction, under the microscope, in dsRNA-injected females that had mature germ cells, it became clear that the surface area decrease had resulted from a decrease in germ cell number, confirmed by the fact that no significant difference of oocyte size was observed between these and the control females. Finally, the most severe phenotype showed an absence of germ cell proliferation, since the oyster remained at the resting stage.

The og-TGF $\beta$ dsRNA injection was also clearly associated with defective germ cell development in some females, which was particularly visible at 34 days post-injection when control oysters reached maturity. For females presenting this second knock-down phenotype, the development of germ cells arrested at the first step of meiosis, before vitellogenesis, led to a large variability of the cellular structure of the gonad with cohorts of germ cells at different developmental 
stages. As a result, we would also expect og-TGF $\beta$ to be positively implicated in the vitellogenesis of female oysters.

Further studies to assess the function of the somatic cells surrounding the germ cells in oysters would be of great interest and should give some indication of how og-TGF $\beta$ functions differentially according to gender. Some previous ultrastructural studies have described somatic cells surrounding the germ cells, as "follicle cells" in mussels (Eckelbarger \& Young, 1999), "Sertoli cells" in clams (Erkan \& Sousa, 2002) or "intragonadal somatic cells" in male oysters (Franco et al., 2010). These cells were found to form a close morphological association with the developing germinal cells, thus suggesting an interaction between them. They are believed to contribute to the synthesis of nutrients and regulatory substances and their transport to the developing germ cells, regulation of mitotic activity of germ cells, phagocytosis of degenerated germ cells, and to serve as a mechanical support for the development of germ cells (Hinsch, 1993). Their putative function(s) in spermatogenesis and oogenesis in marine molluscs still remains to be demonstrated, however.

\subsection{Can og-TGF $\beta$ still be considered a good candidate for further investigation of resistance to summer mortality?}

Based on the lower mRNA level of og-TGF $\beta$ seen in $C$. gigas families displaying low reproductive effort and high resistance to summer mortality, Fleury et al.(2008) suggested that og-TGF $\beta$ has a negative effect in oyster gonad development that could be of benefit to oyster survival. From the in vivo functional inactivation of og-TGF $\beta$ through the use of RNAi (in the present study) or with the heterologous pan-specific anti-TGF $\beta$ polyclonal antibody (Corporeau et al, 2011), it appeared that og-TGF $\beta$ would have a specific enhancing effect on oyster gonad development. This suggests that the significant difference in reproductive effort observed between resistant $(R)$ and susceptible $(S)$ oyster lines might originate from gene(s) other than og-TGF $\beta$ that remain to be discovered. Conversely, a direct or indirect regulation of og-TGF $\beta$ expression by feed-back loops is another possibility that could explain the expression pattern observed in R and $\mathrm{S}$ lines. One of the core concepts of TGF $\beta$ signalling cross-talk is its context dependency. It is clear from several studies that no simple rule can be easily generalized to describe how TGF $\beta$ interacts with any other signalling cascade (e.g., Guo \& Wang, 2009). All experimental data should therefore be interpreted with specific confinement parameters, including cell type, developmental stage, physiological/pathological status, protein intracellular localization, co-factors, identity of targets, etc.. It should also be noted that cross-talk between TGF $\beta$ pathways can be direct or indirect, unidirectional or bidirectional, and often occurs as part of a feed-back loop (Guo \& Wang, 2009; Massagué \& Chen, 2000). On the other hand, synergy or antagonism can also result from independent inputs that do not cross-talk. Therefore, in-depth mechanistic studies are necessary to distinguish the cause from the consequence and to identify the complex regulation of the pathways. One hypothesis that could explain the higher reproductive investment observed in $S$ oysters, resulting in a maximal number of germ cells, might therefore be the activation of feedback loops that would inhibit og-TGF $\beta$ transcription. This hypothesis does not preclude the negative correlation between reproductive effort and resistance to summer mortality suggested in oysters (Huvet et al., 2010) or the possible role of og-TGF $\beta$ in the architecture of the "summer survival" trait, because og-TGF $\beta$ appears to be systematically differentially expressed between $\mathrm{R}$ and $\mathrm{S}$ lines (Huvet et al., 2004; Fleury et al., 2008; Fleury et al., 2010) and was co-localized in one of the five Quantitative Trait Loci associated with summer survival (Sauvage et al., 2010). 


\section{Acknowledgements}

This study was conducted as part of the ANR "Gametogenes" (contract n ${ }^{\circ}$ ANR-08-GENM-041) and the GIS Europole mer "OxyGenes" projects. Many thanks to P. Favrel and C. Lelong for helpful discussions. We thank all the staff of the Argenton experimental hatchery for conditioning the oysters and $\mathrm{H}$. McCombie for her help with the English.

\section{References}

Biswas, S., Criswell, T.L., Wang, S.E., Arteaga, C.L. (2006). Inhibition of transforming growth factor-beta signaling in human cancer: targeting a tumor suppressor network as a therapeutic strategy. Clin Cancer Res 12: 4142-6.

Cadoret, J.P., Debon, R., Cornudella, L., Lardans, V., Morvan, A., Roch, P., Boulo, V. (1999). Transient expression assays with the proximal promoter of a newly characterized actin gene from the oyster Crassostrea gigas. FEBS lett 460: 81-5.

Corporeau, C., Groisillier, A., Jeudy, A., Barbeyron, T., Fleury, E., Fabioux, C., Czjzek, M., Huvet, A. (2011). A functional study of Transforming Growth Factor-beta from the gonad of Pacific oyster Crassostrea gigas. Mar Biotechnol 13: 971-80.

Dégremont, L., Bédier, E., Boudry, P. (2010). Summer mortality of hatchery-produced Pacific oyster spat (Crassostrea gigas). II. Response to selection for survival and its influence on growth and yield. Aquaculture 299: 21-9.

Dégremont, L., Ernande, B., Bédier, E., Boudry, P. (2007). Summer mortality of hatcheryproduced Pacific oyster spat (Crassostrea gigas). I. Estimation of genetic parameters for survival and growth. Aquaculture 262: 41-53.

Eckelbarger, K.J., Young, C.M. (1999). Ultrastructure of gametogenesis in a chemosynthetic mytilid bivalve (Bathymodiolus childressi) from a bathyal, methane seep environment (northern Gulf of Mexico). Mar Biol 135: 635-46.

Elbashir, S.M., Harborth, J., Lendeckel, W., Yalcin, A., Weber, K., Tuschl, T. (2001). Duplexes of 21-nucleotide RNAs mediate RNA interference in cultured mammalian cells. Nature 411: 494-8.

Erkan, M., Sousa, M. (2002). Fine structural study of the spermatogenic cycle in Pitar rudis and Chamelea gallina (Mollusca, Bivalvia, Veneridae). Tissue Cell 34: 262-72.

Ernande, B., Boudry, P., Clobert, J., Haure, J. (2004). Plasticity in resource allocation based life history traits in the Pacific oyster, Crassostrea gigas. I. Spatial variation in food abundance. J Evol Biol 17: 342-56.

Fabioux, C., Huvet, A., Lelong, C., Robert, R., Pouvreau, S., Daniel, J.Y., Minguant, C., Le Pennec, M. (2004). Oyster vasa-like gene as a marker of the germline cell development in Crassostrea gigas. Biochem Biophys Res Commun 320: 592-8.

Fabioux, C., Huvet, A., Le Souchu, P., Le Pennec, M., Pouvreau, S. (2005). Temperature and photoperiod drive Crassostrea gigas reproductive internal clock. Aquaculture 250: 45870.

Fabioux, C., Corporeau, C., Quillien, V., Favrel, P., Huvet, A. (2009). In vivo RNA interference in oyster: vasa silencing inhibits germ cell development. FEBS J. 276, 2566-73.

Fleury, E., Fabioux, C., Lelong, C., Favrel, P., Huvet, A. (2008). Characterization of a gonadspecific transforming growth factor superfamily member differentially expressed during the reproductive cycle of the oyster Crassostrea gigas. Gene 410: 187-196. 
Fleury, E., Moal, J., Boulo, V., Daniel, J.Y., Mazurais, D., Hénaut, A., Corporeau, C., Boudry, P., Favrel, P., Huvet, A. (2010). Microarray-based identification of gonad transcripts differentially expressed between lines of Pacific oyster selected to be resistant or susceptible to summer mortality. Mar. Biotechnol. 12: 326-39.

Fire, A., Xu, S., Montgomery, M.K., Kostas, S.A., Driver, S.E., Mello, C.C. (1998). Potent and specific genetic interference by double-stranded RNA in Caenorhabditis elegans. Nature 391: 806-11.

Franco, A., Jouaux, A., Mathieu, M., Sourdaine, P., Lelong, C., Kellner, K., Heude Berthelin, C. (2010). Proliferating cell nuclear antigen in gonad and associated storage tissue of the Pacific oyster Crassostrea gigas: seasonal immunodetection and expression in laser microdissected tissues. Cell Tissue Res 340: 201-10.

Gautier, A., Le Gac, F., Lareyre, J.J. (2011). The gsdf gene locus harbors evolutionary conserved and clustered genes preferentially expressed in fish previtellogenic oocytes. Gene 472: 7-17.

Guo, X, Wang, XF. (2009). Signaling cross-talk between TGF-beta/BMP and other pathways. Cell Res 19: 71-88.

Hannon, G.J. (2002). RNA interference. Nature 418: 244-51.

Hedgecock, D., Gaffney, P.M., Goulletquer, P., Guo, X.M., Reece, K., Warr, G.W. (2005). The case for sequencing the Pacific oyster genome. J Shellfish Res 24: 429-41.

Herpin, A., Lelong, C., Favrel, P. (2004). Transforming growth factor-beta-related proteins: an ancestral and widespread superfamily of cytokines in metazoans. Dev Comp Immunol 28: 461-85.

Herpin, A., Lelong, C., Becker, T., Rosa, F., Favrel, P., Cunningham, C. (2005). Structural and functional evidence for a singular repertoire of BMP receptor signal transducing proteins in the lophotrochozoan Crassostrea gigas suggests a shared ancestral BMP/activin pathway. FEBS J. 272: 3424-40.

Hinsch, G.W. (1993). Comparative organization and cytology of Sertoli cells in invertebrates, in: Russell, L.D., Griswold, M.D. (eds), The Sertoli cells, Cache River Press, Clearwater, pp. 659-83.

Huvet, A., Herpin, A., Degremont, L., Labreuche, Y., Samain, J.F., Cunningham, C. (2004). The identification of genes from the oyster Crassostrea gigas that are differentially expressed in progeny exhibiting opposed susceptibility to summer mortality. Gene 343: 211-20.

Huvet, A., Normand, J., Fleury, E., Quillien, V., Fabioux, C., Boudry, P. (2010). Reproductive effort of Pacific oysters: a trait associated with susceptibility to summer mortality. Aquaculture 304: 95-9.

Itman, C., Mendis, S., Barakat, B., Loveland, K.L. (2006). All in the family: TGF-beta family action in testis development. Reprod 132: 233-46.

Jiang, Y., Loker, E.S., Zhang, S.M. (2006). In vivo and in vitro knockdown of FREP2 gene expression in the snail Biomphalaria glabrata using RNA interference. Dev Comp Immunol 30: 855-66.

Josso, N., Racine, C., di Clemente, N., Rey, R., Xavier, F. (1998). The role of anti-Mullerian hormone in gonadal development. Mol Cell Endocrinol 145: 3-7.

Knight, P.G., Glister, C. (2006). TGF-beta superfamily members and ovarian follicle development. Reprod 132: 191-206.

Kohli, G., Clelland, E., Peng, C. (2005). Potential targets of transforming growth factor-beta1 during inhibition of oocyte maturation in zebrafish. Reprod Biol Endocrinol 3: 53.

Lango-Reynoso, F., Chavez-Villalba, J., Cochard, J.C., Le Pennec, M. (2000). Oocyte size, a means to evaluate the gametogenic development of the Pacific oyster, Crassostrea gigas (Thunberg). Aquaculture 190: 183-199. 
Latendresse, J.R., Warbrittion, A.R., Jonassen, H., Creasy, D.M. (2002). Fixation of testes and eyes using a modified Davidson's fluid: comparison with Bouin's fluid and conventional Davidson's fluid. Toxicol Pathol 30: 524-33.

Le Quéré, H., Herpin, A., Huvet, A., Lelong, C., Favrel, P. (2009). Structural and functional characterizations of an Activin type II receptor orthologue from the pacific oyster Crassostrea gigas. Gene 436: 101-107.

Livak, K. L., Schmittgen, T. D. (2001). Analysis of relative gene expression data using real time quantitative PCR and the 2-Ct method. Methods 25: 402-8.

Ma, L.J., Jha, S., Ling, H., Pozzi, A., Ledbetter, S., Fogo, A.B. (2004). Divergent effects of low versus high dose anti-TGF-b antibody in puromycin aminonucleoside nephropathy in rats. Kidney Int 65: 106-15.

Martoja, R., Martoja-Pierson, M. (1967). Initiation aux techniques de l'histologie animale, Masson et Cie, Paris, $1232 \mathrm{pp}$.

Massagué, J., Chen, Y.G. (2000). Controlling TGF $\beta$ signalling. Genes Dev 14: 627-44.

Moore, R.K., Erickson, G.F., Shimasaki, S. (2004). Are BMP-15 and GDF-9 primary determinants of ovulation quota in mammals? Trends Endocrinol Metab 15: 356-61.

Samain, J.F., Dégremont, L., Soletchnik, P., Haure, J., Bédier, E., Ropert, M., Moal, J., Huvet, A., Bacca, H., Van Wormhoudt, A., Delaporte, M., Costil, K., Pouvreau, S., Lambert, C., Boulo, V., Soudant, P., Nicolas, J.L., Le Roux, F., Renault, T., Gagnaire, B., Géret, F., Boutet, I., Burgeot, T., Boudry, P. (2007). Genetically based resistance to summer mortality in the Pacific oyster (Crassostrea gigas) and its relationship with physiological, immunological characteristics and infection process. Aquaculture 268: 227-43.

Samain, J.F., McCombie, H. (2008). Summer Mortality of Pacific Oyster Crassostrea gigas. Ed. Ifremer/Quae, Versailles, France.

Sauvage, C., Boudry, P., de Koning, D.J., Haley, C.S., Heurtebise, S., Lapègue, S. (2010). QTL for resistance to summer mortality and OsHV-1 load in the Pacific oyster (Crassostrea gigas). Anim Genet 41: 390-9.

Sawatari, E., Shikina, S., Takeuchi, T., Yoshizaki, G. (2007). A novel transforming growth factorbeta superfamily member expressed in gonadal somatic cells enhances primordial germ cell and spermatogonial proliferation in rainbow trout (Oncorhynchus mykiss). Dev Biol 301: 266-75.

Schulz, C., Kiger, A.A., Tazuke, S.I., Yamashita, Y.M., Pantalena-Filho, L.C., Jones, D.L., Wood, C.G., Fuller, M.T. (2004). A misexpression screen reveals effects of bag-of-marbles and TGF beta class signaling on the Drosophila male germ-line stem cell lineage. Genetics 167: 707-23.

Shim, M. S., Kwon, Y. J. (2010). Efficient and targeted delivery of siRNA in vivo. FEBS J 277: 4814-27.

Shimasaki, S., Moore, R.K., Otsuka, F., Erickson, G.F. (2004). The bone morphogenetic protein system in mammalian reproduction. Endocr Rev 25: 72-101.

Steele, S., Mulcahy, M.F. (1999). Gametogenesis of the oyster Crassostrea gigas in southern Ireland. J Mar Biol Assoc UK 70: 673-86.

Suquet, M., de Kermoysan, G., Araya, R.G., Queau, I., Lebrun, L., Le Souchu, P., Mingant, C. (2009). Anesthesia in Pacific oyster, Crassostrea gigas. Aquat Living Resour 22: 29-34.

ten Dijke, P., Miyazono, K., Heldin, C.H. (2000). Signaling inputs converge on nuclear effectors in TGF-beta signaling. Trends Biochem Sci 25: 64-70.

Vitt, U.A., Hsueh, A.J. (2001). Stage-dependent role of growth differentiation factor-9 in ovarian follicle development. Mol Cell Endocrinol 183: 171-7. 


\section{Tables}

Table 1. Distribution of gametogenic stages (according to the reproductive scale of Steele and Mulcahy, 1999) and sex at 9 and 34 days post-injection in control oysters (injected with saline solution) and oysters injected with og-TGF $\beta$ dsRNA.

\begin{tabular}{|c|c|c|c|c|c|c|c|c|c|}
\hline \multirow[b]{2}{*}{ Time } & \multirow[b]{2}{*}{ Condition } & \multirow[b]{2}{*}{$\mathrm{n}$} & \multicolumn{3}{|c|}{ Sex } & \multicolumn{4}{|c|}{ Gametogenic stage } \\
\hline & & & $\begin{array}{c}\text { undifferentiated } \\
\%\end{array}$ & $\begin{array}{c}\text { female } \\
\%\end{array}$ & $\underset{\%}{\operatorname{male}}$ & $\begin{array}{c}0: \\
\text { undifferentiated } \\
\%\end{array}$ & $\begin{array}{c}1: \\
\text { developing } \\
\text { early } \\
\text { active } \\
\%\end{array}$ & $\begin{array}{c}2: \\
\text { developing } \\
\text { late active } \\
\%\end{array}$ & $\begin{array}{l}3: \\
\text { ripe } \\
\%\end{array}$ \\
\hline T9 & control & 12 & 16.67 & 58.33 & 25 & 8.33 & 25 & 50 & 16.67 \\
\hline T9 & og-TGF $\beta$ & 12 & 16.67 & 58.33 & 25 & 0 & 41.67 & 58.33 & 0 \\
\hline T34 & control & 11 & 0 & 54.55 & 45.45 & 0 & 0 & 9.09 & 90.91 \\
\hline T34 & og-TGF $\beta$ & 11 & 9.09 & 63.64 & 27.27 & 9.09 & 9.09 & 27.27 & 54.55 \\
\hline
\end{tabular}


Figure 1. Levels of og-TGF $\beta$ transcripts relative to actin transcripts, analysed by real-time PCR and expressed in "number of copies of og-TGF $\beta$ per copies of actin" for the control group (white bar; mean of 10 control oysters), for the group of 11 oysters injected with $53 \mu \mathrm{g}$ og-TGF $\beta$ dsRNA (light grey bar), and for the 11 og-TGF $\beta$ dsRNA injected oysters presented individually (light grey bars labelled from 1T to 28T) (34 days post-injection). Error bars represent the $5 \%$ confidence interval. Comparison of the level of mRNA between control and injected groups was performed by Student's t-test, $\left({ }^{*}\right)$ significant at the $5 \%$ level. The horizontal dotted line indicates the threshold of $70 \%$ inhibition for effective RNAi established by Jiang et al. (2006). Red dots show the gonad area (given in \%) according to the scale on the secondary $Y$ axis.

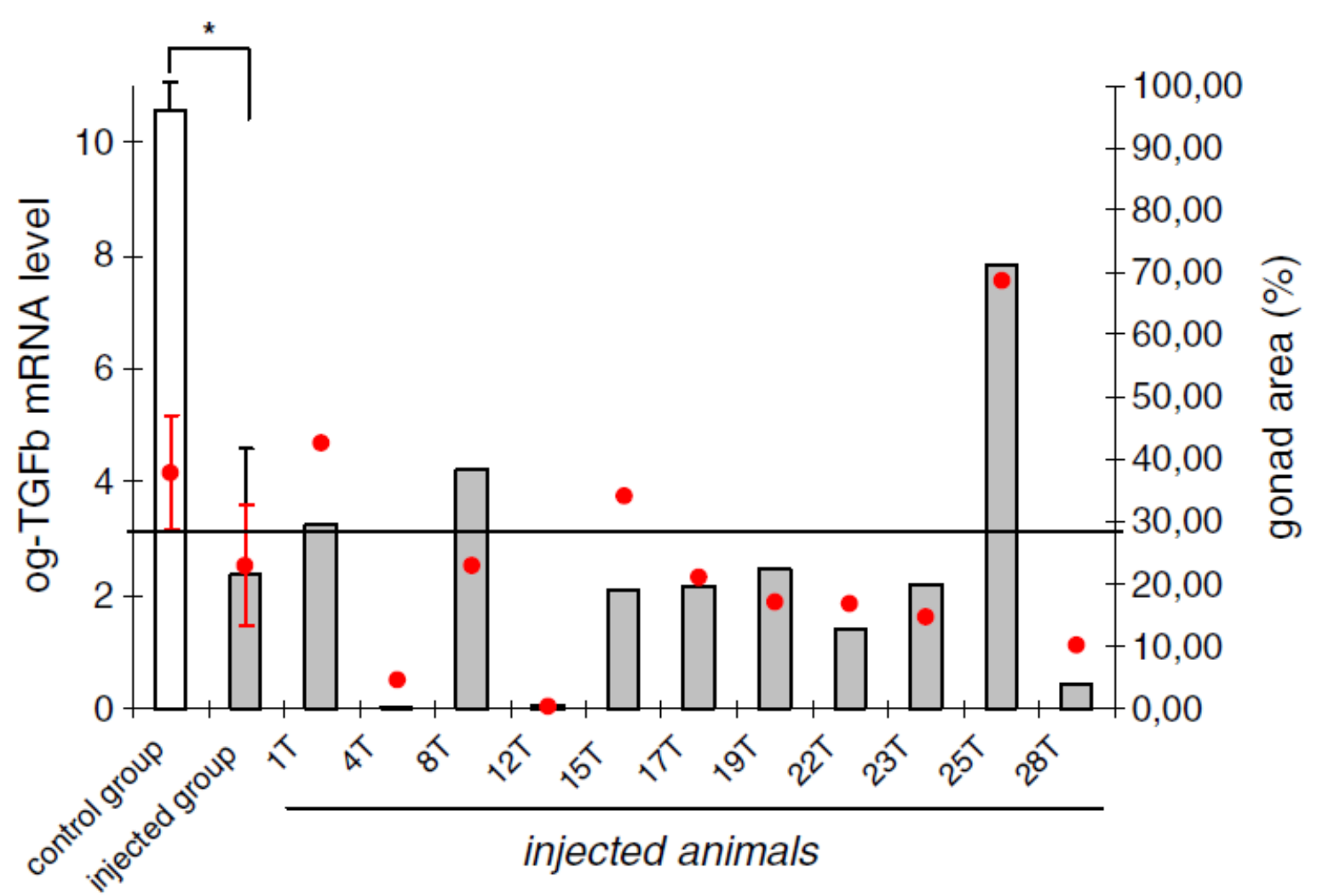


Figure 2. Under-proliferation of germ cells, one knock-down phenotype observed for in vivo ogTGF $\beta$ dsRNA-injected oysters, 34 days post-injection.

(A) Female control, injected with saline solution. Gonadal tubules are confluent and filled with

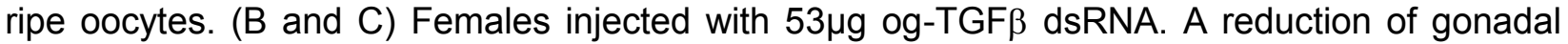
tubules is observed, due to a decrease in germ cell number, moderate in $B\left(n^{\circ} 8 T\right)$ and harsh in $C\left(n^{\circ} 17 T\right)$. (D) Male control injected with saline solution. Gonadal tubules are confluent and filled

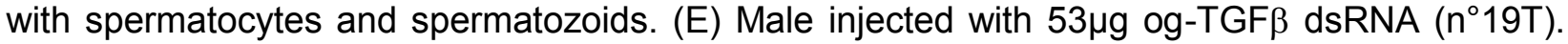
Gonadal tubules are reduced in size compared to control and filled with a limited number of

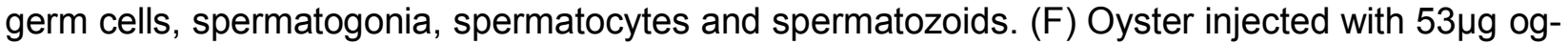
TGF $\beta$ dsRNA ( $\mathrm{n}^{\circ} 12 \mathrm{~T}$ ) blocked at resting stage without any sign of proliferation of germinal stem cells.

Gt: Gonadal Tubule; Ct: Conjunctive Tissue; DG: Digestive Gland; GSC: Germinal Stem Cells. Magnification 100x. Scale bars represent 100 $\mathrm{m}$.
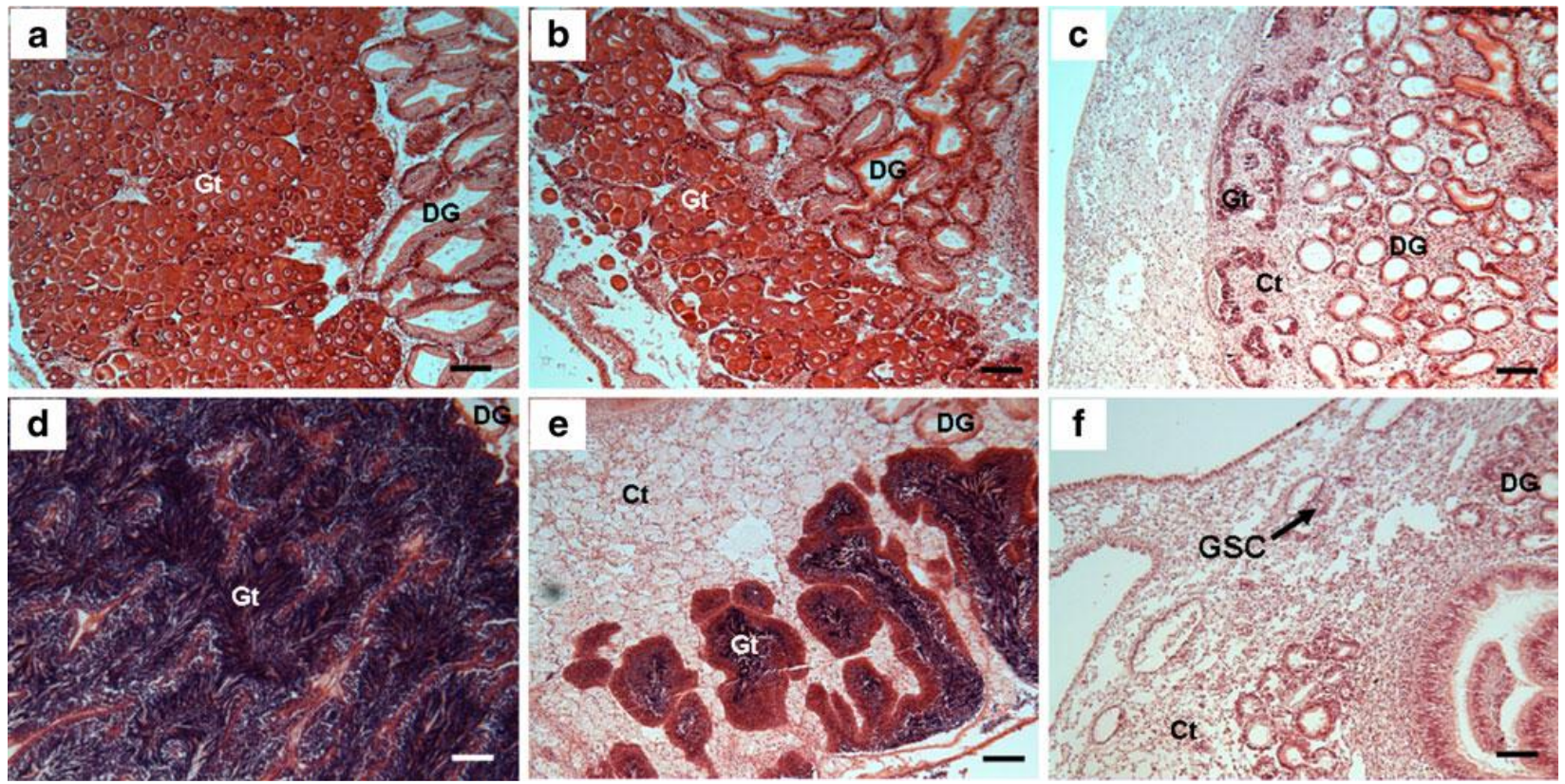
Figure 3. Defects in oocyte maturation, a second knock-down phenotype observed for in vivo ogTGF $\beta$ dsRNA injected females, 34 days post-injection.

(A) Ripe oocytes in the female control. (B) For half of the og-TGF $\beta$ dsRNA-injected females, we only observed oocytes I before vitellogenesis in gonadal tubules and apoptosis figures with apoptotic oocytes and haemocyte invasion in the tubules. OI: Oocyte I; VO: Vitellogenic Oocyte; ApO: Apoptotic Oocyte; H: Haemocytes. Magnification 400x. Scale bars represent 50 um.
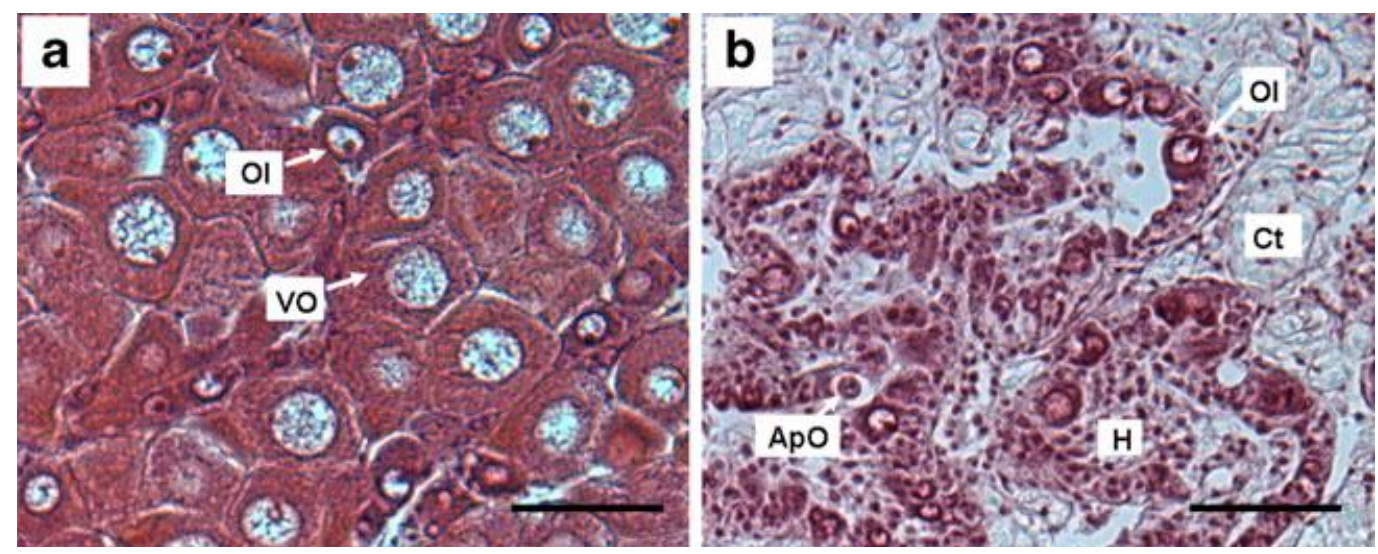